\title{
NOTE AND COMMENT
}

\author{
INTERPRETIVE RULEMAKING AND THE ALASKA HUNTERS \\ DOCTRINE: A NECESSARY LIMITATION ON AGENCY \\ DISCRETION
}

\begin{abstract}
Ryan DeMotte
Kenneth Culp Davis ${ }^{1}$

inventions of modern government.
\end{abstract}

\section{INTRODUCTION}

Administrative agencies govern a vast amount of our personal and economic lives. ${ }^{2}$ Whether buying groceries or visiting a national park, selling shares of stock or taking medication, individuals are impacted every day by federal agencies and the regulatory regimes they administer. ${ }^{3}$ Federal regulations govern many of the significant decisions made by corporations and businesses. ${ }^{4}$ Given the immense scope and impact of federal regulation, the public has an important interest in ensuring that agency administration is both

\footnotetext{
* The author would like to thank Professor John Parry and Mr. Nicholas Ranjan for helpful comments on prior drafts of this note. Special thanks to Bonnie, Maria, and Jake for their patience and support during the writing process.

1. Kenneth Culp Davis, Discretionary Justice: A Preliminary Inquiry 65 (1969).

2. See Cornelius M. Kerw in, Rulemaking: How Government Agencies Write Law and Make Policy 4 (3d ed. 2003).

3. See id. at 2 .

4. See Peter L. Strauss, Administrative Justice in the United States 152-53 (2d ed. 2002).
} 
fair and efficient. ${ }^{5}$ Central to achieving fairness and efficiency in agency administration is the Administrative Procedure Act ("APA"), the fundamental law governing federal agencies. ${ }^{6}$ The APA establishes the basic procedural requirements for agency action, and provides for judicial review. ${ }^{7}$

Among the most important contributions of the APA is the establishment of notice-and-comment rulemaking. ${ }^{8}$ Notice-and-comment rulemaking is the process by which agencies create the regulations that legally bind the public. ${ }^{9}$ Notice-and-comment rulemaking requires that agencies give notice of a proposed rulemaking to the public and accept comments and data on the proposed rule before final promulgation..$^{10}$ Through notice-and-comment, the public is able to participate in the process of establishing the regulations that will ultimately govern them. ${ }^{11}$ Notice-and-comment rules (commonly referred to as "legislative" rules) have the "force of law," meaning they have the same legal effect as statutes passed by Congress. ${ }^{12}$ These legislative rules establish the core duties and obligations of regulated parties. ${ }^{13}$

While legislative rules establish the duties and obligations that govern regulated parties, in order to actually administer and enforce regulations, agencies must interpret legislative rules and apply them to individual situations. ${ }^{14}$ Agencies are constantly called upon to interpret the concrete duties and obligations established by their regulations. ${ }^{15}$ Because regulations cannot address with detailed precision every circumstance in which they might be applied, interpretation is necessary to fill in the gaps and resolve ambiguities. ${ }^{16}$ Agency interpretation of legislative rules is central to effective administration. ${ }^{17}$ Since an agency must take some stand on the meaning of a legislative rule in order to apply it, interpretation theoretically occurs any time

5. See Kerw In, supra note 2, at 32-33.

6. See Jefrrey S. Lubbers, A Guide to Federal Agency Rulemaking 5 (3d ed. 1998).

7. Id. at 5,7 .

8. See DAVIS, supra note 1, at 65.

9. See KeRW IN, supra note 2, at 3.

10. 5 U.S.C. $\$ 553$ (b)-(c) (2000).

11. See Davis, supra note 1, at 65 .

12. William Funk, A Primer on Nonlegislative Rules, 53 ADMIN. L. REv. 1321, 1322 (2001).

13. See KeRw IN, supra note 2, at 2.

14. See Robert A. Anthony, Interpretive Rules, Policy Statements, Guidances, Manuals, and the Like-Should Federal Agencies Use Them To Bind the Public, 41 Duke L.J. 1311, 1375-76 (1992) ("The agency has the responsibility to administer and enforce the statute, and in order to get on with that job it must be able to take a position as to the meaning of the statute or regulation it is interpreting.").

15. See id.

16. Richard J. Pierce, Jr., Distinguishing Legislative Rules from Interpretive Rules, 52 Admin. L. Rev. 547, 553 (2000).

17. See Anthony, supra note 14, at 1375-76. 
the agency administers or enforces a particular legislative rule. However, agencies accomplish much of their interpretation of legislative rules through the process of interpretive rulemaking. ${ }^{18}$

An interpretive rule is a statement informing regulated parties in advance of an agency's interpretation of a particular legislative rule. ${ }^{19}$ Because the APA defines an agency rule broadly as "the whole or a part of an agency statement of general or particular applicability and future effect designed to implement, interpret, or prescribe law or policy or describing the organization, procedure, or practice requirements of an agency, ${ }^{, 20}$ interpretive rules come in a wide variety of formats, from official publications in the Code of Federal Regulations, to technical compliance manuals, to informal letters from agency personnel providing advice and guidance to regulated parties. ${ }^{21}$

Interpretive rules are distinguished from legislative rules in that interpretive rules merely interpret the existing duties and obligations embodied in a legislative rule. ${ }^{22}$ Because of this, interpretive rules do not have the "force of law" like legislative rules and are therefore exempt from noticeand-comment procedures under the APA. ${ }^{23}$ However, because they indicate how an agency will interpret a regulation in an enforcement proceeding, interpretive rules are often practically binding on regulated parties. ${ }^{24}$ This combination of procedural freedom and the ability to practically bind regulated parties creates a substantial incentive for agencies to narrow the scope of notice-and-comment rulemaking and correspondingly increase the scope of interpretive rulemaking. ${ }^{25}$ Agencies can accomplish this by deliberately proposing vaguely worded legislative rules in order to fill in the details with interpretive rulemaking. ${ }^{26}$

The incentive to avoid notice-and-comment rulemaking through interpretive rulemaking has increased over time, as both the time and cost of notice-and-comment rulemaking has increased. ${ }^{27}$ Because legislative rules

18. Peter L. Strauss, Publication Rules in the Rulemaking Spectrum: Assuring Proper Respectfor an Essential Element, 53 Admin. L. Rev. 803, 804-05 (2001).

19. See id.

20. 5 U.S.C. $\S 551(4)(2000)$.

21. See Funk, supra note 12, at 1322-23.

22. Anthony, supra note 14, at 1324.

23. See id. at 1327,1375 .

24. See id. at 1328-29.

25. See Thomas O. McGarity, Some Thoughts on "Deossifying" the Rulemaking Process, 41 DuKE L.J. 1385, 1393 (1992)

26. See id. at 1393-94.

27. See id. at 1385-86. 
"make" the law that will govern entire industries, the stakes are often very high, with potential economic costs running several hundred million dollars for a single rule. ${ }^{28}$ Given the consequences, agency rulemaking is subject to intense political scrutiny. ${ }^{29}$ This scrutiny has led both Congress and the executive branch to impose substantial procedural and analytical requirements on agency rulemaking beyond those required by the Administrative Procedure Act. $^{30}$

Because of the strong incentive to avoid notice-and-comment through interpretive rulemaking, courts have attempted to establish clear limits on the use of the interpretive rule exemption. ${ }^{31}$ One of these limitations is that an interpretive rule cannot amend a prior legislative rule. ${ }^{32}$ An agency must use notice-and-comment rulemaking to amend or reverse a legislative rule. ${ }^{33}$ However, there is disagreement among circuits about whether to extend this limitation to interpretive rules that amend or reverse a definitive interpretation of a legislative rule. ${ }^{34}$ In this context, the legislative rule is subject to various reasonable interpretations: the interpretive rule does not amend or reverse the text of the legislative rule; rather, it amends or reverses an agency's definitively established interpretation of the ambiguous text of the legislative rule. Therefore, interpretive rules are of two types: those that amend or reverse definitive interpretations and those that merely clarify an ambiguity in the legislative rule.

Many circuits follow the approach to interpretive rulemaking developed by the D.C. Circuit in 1993 in American Mining Congress v. Mine Safety \& Health Administration, which does not require notice-and-comment for interpretive rules that amend or reverse a definitive interpretation. ${ }^{35}$ Other

28. At the end of 2001 , there were 149 "economically significant" rules (rules estimated to have at least $\$ 100$ million dollars in economic impact) at various stages in the rulemaking process. CLYDE WAYNE Crews, Jr., Ten Thousand Commandments: An Annual Snapshot of the Federal Regulatory STATE 1 (2002 ed.), available at http://www.cato.org/tech/pubs/10kc_2002.pdf.

29. KERW IN, supra note 2, at 43.

30. See LubBers, supra note 6, at 108-35.

31. See Am. Fed'n Gov't Employees v. Block, 655 F.2d 1153, 1156 (D.C. Cir. 1981) (stating that exemptions to notice-and-comment are to be "narrowly construed and only reluctantly countenanced").

32. Am. Mining Cong. v. Mine Safety \& Health Admin., 995 F.2d 1106, 1109 (D.C. Cir. 1993).

33. Id.

34. 1 Richard J. Pierce, Jr., Administrative Law Treatise $\S 6.4$, at 50 (4th ed. Supp. 2004).

35. American Mining, 995 F.2d at 1106. See Warder v. Shalala, 149 F.3d 73, 80 (1st Cir. 1998); Mission Group Kan., Inc. v. Riley, 146 F.3d 775, 784 (10th Cir. 1998); Appalachian States Low-Level Radioactive Waste Comm'n v. O'Leary, 93 F.3d 103, 113 (3d Cir. 1996); Hoctor v. Dep't of Agric., 82 F.3d 165, 171 (7th Cir. 1996); Chen Zhou Chai v. Carroll, 48 F.3d 1331, 1340 (4th Cir. 1995); N.Y. City Employees' Ret. Sys. v. SEC, 45 F.3d 7, 13-14 (2d Cir. 1995); Nat'1 Org. of Veterans Advocates v. Sec'y of Veterans Affairs, 260 F.3d 1365, 1375-76 (Fed. Cir. 2001). See also 1 Richard J. Pierce, JR., 
circuits, including the D.C. Circuit itself, have modified the American Mining test to require notice-and-comment for interpretive rules that amend or reverse definitive interpretations. ${ }^{36}$ This doctrine was first articulated by the D.C. Circuit in dicta in Paralyzed Veterans of America v. D.C. Arena L.P. and first applied to a decision in Alaska Professional Hunters Ass' $n$ v. FAA. ${ }^{37}$

Both regulated parties and agencies have a considerable stake in the resolution of this issue. From the perspective of regulated parties, imposing notice-and-comment on interpretive rules that amend or reverse definitive interpretations will place a significant procedural check on agency discretion. ${ }^{38}$ Regulated parties will be guaranteed the opportunity to participate in any significant interpretive changes, giving them greater input into the process of defining their duties and obligations. ${ }^{39}$ Conversely, agencies view maximum flexibility in interpretive rulemaking as necessary in order to ensure that legislative rules maintain effectiveness in the face of changed circumstances. ${ }^{40}$ From the agency perspective, any limit on the ability to amend or reverse interpretations necessarily hinders the ability of agencies to adapt to these changing circumstances. ${ }^{41}$

This Note argues that interpretive rules that amend or reverse definitive interpretations must go through notice-and-comment procedures to ensure that interpretive changes are fair and rational. Part II discusses the alternative approaches to interpretive rulemaking, represented by American Mining and Alaska Hunters, and argues that subsequent applications of the Alaska Hunters doctrine have appropriately limited its scope so that it does not unnecessarily interfere with agency interpretive flexibility. Part III argues that the Alaska Hunters doctrine preserves public participation in important policy decisions and protects the legitimate reliance interests of regulated parties. It further argues that judicial review of agency interpretations under $\S 706(2)$ (a) is not sufficient to vindicate the interests of regulated parties implicated by

Administrative Law Treatise $\S 6.4$, at 345-46 (4th ed. 2002).

36. Shell Offshore Inc. v. Babbitt, 238 F.3d 622, 629 (5th Cir. 2001); Alaska Prof'l Hunters Ass'n v. FAA, 177 F.3d 1030, 1035-36 (D.C. Cir. 1999).

37. Alaska Hunters, 177 F.3d at 1033-34; Paralyzed Veterans of Am. v. D.C. Arena, L.P., 117 F.3d 579, 586 (D.C. Cir. 1997).

38. See McGarity, supra note 25, at 1393-96 (describing the drawbacks of increased "nonrule" rulemaking (a reference to non-legislative rulemaking) and the benefits of fairness and public participation inherent in notice-and-comment rulemaking).

39. See Anthony, supra note 14, at 1376 (discussing the benefits of notice-and-comment rulemaking in the context of substantial interpretive changes).

40. Jon Connolly, Note, Alaska Hunters and the D.C. Circuit: A Defense of Flexible Interpretive Rulemaking, 101 Colum. L. REV. 155, 172 (2001).

41. Id. 
substantial interpretive changes. Part IV argues that Alaska Hunters properly adopts a functional interpretation of the interpretive rule exemption, recognizing that over time established and definitive interpretations become functionally inseparable from the legislative rules they interpret. This Note concludes that courts should adopt the Alaska Hunters doctrine and require notice-and-comment for interpretive rules that amend or reverse definitive interpretations of legislative rules. ${ }^{42}$

\section{Alaska Hunters And American Mining: Current Doctrine}

\section{A. American Mining Doctrine}

In American Mining, the D.C. Circuit sought to bring coherence and stability to its interpretive rule jurisprudence by articulating a clear, comprehensive set of factors that could be used to distinguish interpretive rules from legislative rules. ${ }^{43}$ The resulting test, although largely successful in bringing clarity to the distinction between legislative and interpretive rules, does not adequately resolve the issue of interpretive rules that amend or reverse definitive interpretations.

In American Mining, the court addressed the issue of whether Program Policy Letters ("PPLs"), issued by the Mine Safety and Health Administration ("MSHA"), qualified as interpretive rules under the APA and were therefore exempt from notice-and-comment requirements. ${ }^{44}$ The PPLs presented the agency's interpretation of its legislative rule requiring each mine operator "to report to the MSHA within ten days 'each accident, occupational injury, or occupational illness' that occurs at a mine." ${ }^{, 45}$ The rule further required that "occupational illnesses" be reported within ten days of being "diagnosed." 46

The MSHA issued three interpretive PPLs, which were "intended to coordinate and convey agency policies, guidelines, and interpretations to agency employees and interested members of the public. ${ }^{\$ 47}$ The PPLs clarified the minimum x-ray reading required for a "diagnosis" and the

42. Alaska Hunters, 177 F.3d at 1033-34 (quoting Paralyzed Veterans, 117 F.3d at 586).

43. Am. Mining Cong. v. Mine Sa fety \& Health Admin., 995 F.2d 1106, 1112 (D.C. Cir. 1993); see also Pierce, supra note 16, at 573 (praising the American Mining opinion as "the most comprehensive and best-reasoned explanation of the distinction between legislative and interpretative rules that has ever been published").

44. American Mining, 995 F.2d at 1107.

45. $I d$.

46. $I d$.

47. $I d$. 
qualifications of the x-ray reader. ${ }^{48}$ The MSHA did not follow notice-andcomment procedures for any of the PPLs. ${ }^{49}$ The plaintiff argued that the PPLs were legislative rules and therefore required to be promulgated through noticeand-comment. ${ }^{50}$

According to the court, the basic distinction between legislative and interpretive rules was whether a rule had "the force of law." A rule has the "force of law" only if "Congress has delegated legislative power to the agency and if the agency intended to exercise that power in promulgating the rule." ${ }^{52}$ The court gave content to its "intent to exercise" language by establishing a comprehensive list of criteria to distinguish legislative from interpretive rules:

(1) whether in the absence of the rule there would not be an adequate legislative basis for enforcement action or other agency action to confer benefits or ensure the performance of duties (2) whether the agency has published the rule in the Code of Federal Regulations (3) whether the agency has explicitly invoked its general legislative authority or (4) whether the rule effectively amends a prior legislative rule. If the answer to any of these questions is affirmative, we have a legislative, not an interpretive rule. ${ }^{53}$

Applying this test, the court concluded that the PPLs were interpretive rules. ${ }^{54}$

The court indicated that the limitation on amending legislative rules (the fourth factor) should not be read too broadly. ${ }^{55}$ According to the court, "a rule does not, in this inquiry, become an amendment merely because it supplies crisper and more detailed lines than the authority being interpreted." ${ }^{.56}$ The

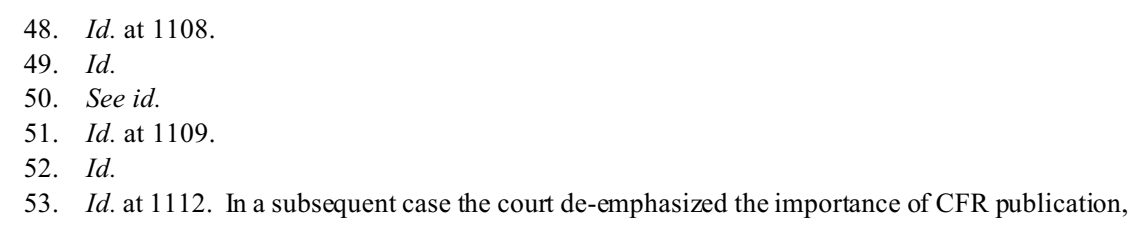
stating that it constituted no more than "a snippet of evidence of agency intent." Health Ins. Ass'n of Am. v. Shalala, 23 F.3d 412, 423 (D.C. Cir. 1994). Professor Richard Pierce has compiled an amended four-factor test, excluding CFR publication and including the following factor: "whether the legislative rule the agency is claiming to interpret is too vague or open-ended to support the interpretative rule." PIERCE, supra note 35, at 345. The court discussed this factor in dicta in American Mining, 995 F.2d at 1110.

54. American Mining, 995 F.2d at 1112. Under the first factor, since the "regulations themselves require the reporting of diagnoses of the specified diseases, ... there is no legislative gap that required the PPL as a predicate to enforcement action." Id. Considering the second and third factor, the agency did not "purport to act legislatively, either by including the letter in the Code of Federal Regulations, or by invoking its general legislative authority ...." Id. Under the fourth factor, the court concludes that, while some definitions of "diagnosis" require additional diagnostic tools beyond x-rays, "[a] finding of a disease is surely equivalent, in normal terminology, to a diagnosis, and thus the PPLs certainly offer no interpretation that repudiates or is irreconcilable with an existing legislative rule." Id. at 1112-13.

55. See id. at 1112 .

56. Id. 
court expressed more general skepticism about placing unnecessary limits on interpretive rulemaking:

The protection that Congress sought to secure by requiring notice and comment for legislative rules is not advanced by reading the exemption for "interpretive rule" so narrowly as to drive agencies into pure ad hocery - an ad hocery, moreover, that affords less notice, or less convenient notice, to affected parties. ${ }^{57}$

Thus, because the fourth factor only applies to legislative rules, the American Mining test places no limitations on interpretive rules that effectively amend prior definitive interpretations of legislative rules. ${ }^{58}$

\section{B. Paralyzed Veterans/Alaska Hunters Doctrine}

In Paralyzed Veterans, the court effected a major change in the application of the fourth factor of the American Mining test by applying it to interpretive rules that effectively amend definitive interpretations of legislative rules, in addition to interpretive rules that effectively amend the legislative rules themselves. ${ }^{59}$ According to the court, "[t]o allow an agency to make a fundamental change in its interpretation of a substantive regulation without notice and comment obviously would undermine [the notice-andcomment] requirements. ${ }^{\circ 0}$ This language in Paralyzed Veterans was only dicta, and it was not until Alaska Hunters that the principle was applied to a decision. ${ }^{61}$ Further application of the doctrine indicated that it would be read narrowly, limited to only those interpretive rules that were clearly definitive and had generated settled expectations. ${ }^{62}$ This ensures that the doctrine will not place unnecessary restrictions on agency flexibility.

In Alaska Hunters, the court directly addressed the issue of whether an agency was required to follow notice-and-comment procedures to promulgate an interpretive rule that amended or reversed a prior definitive interpretation. ${ }^{63}$ In 1998, the Federal Aviation Administration ("FAA") published a document

57. $I d$.

58. Pierce, supra note 16, at 570 (asserting that, based on its reasoning, the American Mining court "necessarily held that an interpretative rule can amend a prior interpretative rule").

59. Paralyzed Veterans of Am. v. D.C. Arena, L.P., 117 F.3d 579, 586 (D.C. Cir. 1997).

60. Id.

61. See Pierce, supra note 16 , at 563.

62. See Darrell Andrews Trucking, Inc. v. Fed. Motor Carrier Safety Admin., 296 F.3d 1120, 1125-30 (D.C. Cir. 2002); Air Transp. Ass'n of Am., Inc. v. FAA, 291 F.3d 49, 58 (D.C. Cir. 2002); Ass'n of Am. R.R.s v. Dep't of Transp., 198 F.3d 944, 947-48 (D.C. Cir. 1999).

63. Alaska Prof'l Hunters Ass'n v. FAA, 177 F.3d 1030, 1030-31 (D.C. Cir. 1999). 
entitled "Notice to Operators" directed to Alaskan hunting and fishing guides who transport customers in light aircraft as part of their guiding service. ${ }^{64}$ The Notice required the pilots to abide by FAA regulations applicable to commercial pilots. ${ }^{65}$ The Notice was an interpretation of an FAA regulation requiring that "commercial operator[s]," defined as persons operating aircraft "for compensation or hire," comply with commercial air operations regulations. ${ }^{66}$ This reversed a definitive interpretation that had been in place for more than thirty years. ${ }^{67}$ According to the court, "[b] eginning in 1963, the FAA, through its Alaskan Region, consistently advised guide pilots that they were not governed by regulations dealing with commercial pilots." ${ }^{968}$ The court further stated that "[a]lthough the Alaskan Region never set forth its interpretation of [the commercial air regulations] in a written statement, all agree that FAA personnel in Alaska consistently followed the interpretation in official advice to guides and guide services. ${ }^{, 69}$

The court then applied the Paralyzed Veterans rule: "When an agency has given its regulation a definitive interpretation, and later significantly revises that interpretation, the agency has in effect amended its rule, something it may not accomplish without notice and comment." ${ }^{, 70}$ The court emphasized both the reliance interests of the guide pilots and their lack of participation in the development of the commercial air regulations to justify the requirement of notice-and-comment. ${ }^{71}$ According to the court, "Alaskan guide pilots and lodge operators relied on the advice FAA officials imparted to them - they opened lodges and built up businesses dependent on aircraft, believing their flights were [not] subject to [the commercial air regulations].",72 The court stated: "[T]hat advice became an authoritative departmental interpretation, an administrative common law applicable to Alaskan guide pilots." ${ }^{\text {73 }}$ Further, the court emphasized that Alaskan guide pilots did not participate in the numerous modifications to the commercial air operations regulations, believing they were exempt. ${ }^{74}$ According to the court,

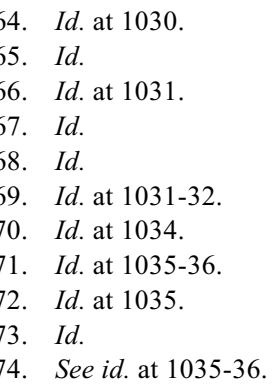


[h] ad guides and lodge operators been able to comment on the resulting amendments and modifications to [the commercial air regulations], they could have suggested changes or exceptions that would have accommodated the unique circumstances of Alaskan air carriage .... There is no reason to suppose that with the participation of Alaskan guide pilots and lodge operators, the [commercial air regulations] would not have been affected. If the FAA now wishes to apply those regulations to these individuals, it must give them an opportunity to comment before doing so. ${ }^{75}$

Therefore, the court concluded that " $\mathrm{t}]$ he Notice to Operators was published without notice and comment and it is therefore invalid."

In the same year, the court clarified the limitations of Alaska Hunters in Association of American Railroads v. Department of Transportation. ${ }^{77}$ In American Railroads, the plaintiff challenged an interpretation of a safety regulation in a technical bulletin issued by the Federal Railroad Administration ("FRA"). ${ }^{78}$ The plaintiff contended that the bulletin reversed a prior agency interpretation and therefore was required by Alaska Hunters to go through notice-and-comment. ${ }^{79}$ According to the plaintiff, the technical bulletin, which required railroads to inform an oncoming train's engineer of a work flag's precise location, reversed the prior definitive interpretation of the FRA requiring only that the train be informed of the range in which the flag would be located. ${ }^{80}$

The plaintiff relied on statements in the Preamble to the Roadway Worker Protection Rule, an e-mail and two letters from agency personnel, and the agency's own safety manual to support its claim that a definitive agency interpretation had been reversed by the technical bulletin. ${ }^{81}$ The court rejected the contention that these sources established a definitive interpretation. ${ }^{82}$ The Rule's preamble stated only that "working limits are delineated by flags as specified in [paragraph] (c)(5)." " According to the court, "[the preamble] says nothing about whether notice of the flag's precise location is required." ${ }^{.84}$ The e-mail message also did not specifically address the issue of notice. ${ }^{85}$

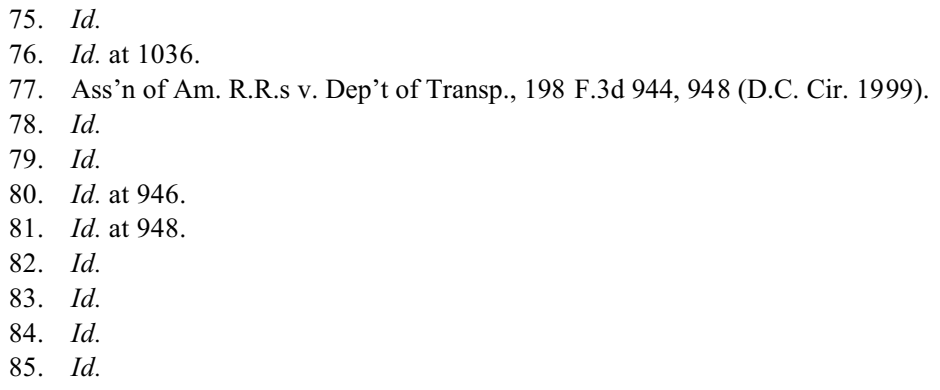


More importantly, it was sent by an FRA bridge engineer with no policymaking authority. ${ }^{86}$ The two letters, from the Acting FRA Associate Administrator for Safety and his subordinate, provided some support for the plaintiff's position. ${ }^{87}$ They indicated that flags may move in the controlled areas and that trains must be aware of the track segment within which the flags are located. ${ }^{88}$

However, the FRA pointed to contrary evidence of its own that supported the stricter interpretation. ${ }^{89}$ Specifically, the FRA pointed to several reports that indicated that violations had been found based on the failure to adhere to the stricter flag-placement standard. ${ }^{90}$ The FRA also asserted that the instructions in the General Code of Operating Rules, a set of model procedures given to railroads, effectively instructed the railroads to adhere to the stricter rule. ${ }^{91}$

Based on this evidence, the court refused to apply Alaska Hunters, distinguishing the ambiguous and contradictory interpretations of the FRA from the definitive interpretation adopted by the FAA in Alaska Hunters. ${ }^{92}$ According to the court,

[e]ven interpreting the evidence in the light most favorable to [the plaintiff], however, we think it is quite clear that the FRA never adopted a definitive interpretation of [the flag placement requirement] that it could change only through notice and comment rulemaking. Although the AAR has unearthed some documents that seem, albeit sometimes vaguely, to support its argument that the agency - or at least some of its employees - may have interpreted [the flag placement requirement] as not requiring notice of precise flag location, none of those documents even comes close to the express, direct, and uniform interpretation present in Alaska Hunters. ${ }^{93}$

Also, the court noted that prior to the technical bulletin, the issue of flag location had never been the subject of an official agency proceeding. ${ }^{94}$ In American Railroads, there is no comparable Alaska Hunters-like "administrative common law." 95 The court also placed importance on reliance interests, noting that " $[\mathrm{n}]$ othing in this record suggests that railroads relied on

\footnotetext{
86. $I d$.

87. Id.

88. Id.

89. Id. at 949 .

90. Id.

91. $I d$.

92. Id.

93. Id.

94. Id. at $949-50$

95. Id. at 950 .
} 
the [interpretive documents] in any comparable way [to the Alaskan guide pilots]." ${ }^{.96}$

More recent applications of Alaska Hunters have reinforced the limited scope of the doctrine as applied in American Railroads. ${ }^{97}$ In Darrell Andrews Trucking v. Federal Motor Carrier Safety Administration, the D.C. Circuit addressed the issue of the FMCSA's interpretation of a legislative rule requiring trucking companies to "maintain records of duty status and all supporting documents for each driver ...." The FMCSA interpreted "supporting documents" to mean documents that could be used to verify the accuracy of a driver's record as opposed to documents actually used by the trucking company to verify a driver's record. ${ }^{99}$ The plaintiff contended that this interpretation was a significant change from a previous, definitive interpretation requiring the company to maintain only those records actually used to verify a driver's record. ${ }^{100}$ In support of its contention, the plaintiff pointed to a regulatory guidance, issued in 1993 and reissued verbatim in 1997, and language in a 1998 Notice of Proposed Rulemaking ("NPRM") for a rule that was never promulgated. ${ }^{101}$ The guidances contained language that supported the "actually used" interpretation, while the NPRM contained language proposing to adopt the "could be used" interpretation, which, according to the plaintiff's theory, implied that prior to the NPRM the agency had adhered to the "actually used" interpretation. ${ }^{102}$ The court rejected the argument that these documents established a definitive interpretation. ${ }^{103}$ The court pointed to language in the guidances that actually supported the "could be used" interpretation, while it declined to infer the existence of a definitive "actually used" interpretation based solely on the NPRM proposing the adoption of the "could be used" interpretation. ${ }^{104}$ More importantly to the court, the FMCSA had adopted the "could be used" interpretation in informal adjudication at the same time that these ambiguous documents were issued. ${ }^{105}$

96. Id.

97. Alaska Prof'1 Hunters Ass'n v. FAA, 177 F.3d 1030, 1030 (D.C. Cir. 1999); American Railroads, 198 F.3d at 944.

98. Darrell Andrews Trucking, Inc. v. Fed. Motor Carrier Safety Admin., 296 F.3d 1120, 1123 (D.C.

Cir. 2002) (citing 49 C.F.R. $\S 395.8(\mathrm{~K})(1)$ ).

99. Id. at 1125 .

100. $I d$.

101. Id. at 1126 .

102. Id. at 1126-27.

103. $I d$.

104. $I d$.

105. Id. at 1127. 
The court concluded that because the interpretive documents were ambiguous and because contemporaneous informal adjudication actually affirmed the agency's position, the plaintiff "[was] therefore unable to show that the decision below represent[ed] a substantial change in the agency's construction of [the regulation]." 106

In Air Transport Ass 'n of America v. Federal Aviation Administration, the D.C. Circuit adopted a narrow reading of a prior interpretation in order to conclude that it was not "significantly revise[d]" by a new interpretation for purposes of the Alaska Hunters doctrine. ${ }^{107}$ At issue was the interpretation of FAA regulations requiring certain minimum rest periods between flights for pilots. ${ }^{108}$ In a document entitled "Interpretation 1992-24," which explained the requirements for calculating rest periods, the FAA stated that "deviations encountered in the operation of an otherwise legitimately scheduled flight are permitted." ${ }^{109}$ The plaintiff understood this language to mean that certain calculations of rest periods could be based on scheduled flight times rather than actual expected flight times based on flight-day conditions. ${ }^{110}$ Thus, when FAA Deputy Counsel James Whitlow issued a letter requiring calculations to be based on actual expected flight times, the plaintiff challenged the new interpretation under the Alaska Hunters doctrine. ${ }^{11}$ The FAA countered that "Interpretation 1992-24" addressed only short flight delays, not the longer flight delays addressed by the "Whitlow letter."112 According to the court, "[a]lthough Interpretation 1992-24 was not expressly limited to short delays, it nevertheless does not provide a 'definitive' interpretation inconsistent with that of the Whitlow Letter." 113 The court read a short-delay limitation into "Interpretation 1992-24" in order to reconcile it with the "Whitlow Letter" and avoid an Alaska Hunters issue. ${ }^{114}$

This Part establishes the basic distinction between American Mining and Alaska Hunters: The American Mining test places no limitations on interpretive rules that amend or reverse definitive interpretations, ${ }^{115}$ while the Alaska Hunters doctrine requires notice-and-comment for those interpretive

106. Id. at 1128 .

107. Air Transp. Ass'n of Am. Inc. v. FAA, 291 F.3d 49, 58 (D.C. Cir. 2002).

108. Id. at 51 .

109. Id. at 57 .

110. $I d$.

111. Id. at 56.

112. Id. at 57 .

113. $I d$.

114. Id. at $57-58$.

115. Am. Mining Cong. v. Mine Safety \& Health Admin., 995 F.2d 1106, 1106 (D.C. Cir. 1993). 
rules that amend or reverse a definitive interpretation. ${ }^{116}$ This Part further identifies four important limitations placed on Alaska Hunters by subsequent applications: First, the interpretation must be uniform and unambiguous - any contradiction or ambiguity in an agency interpretation will render the doctrine inapplicable; ${ }^{117}$ second, prior agency interpretations must be construed narrowly to avoid a potential interpretive conflict; ${ }^{118}$ third, the interpretation must have been the subject of an official agency proceeding $;{ }^{119}$ and fourth, regulated parties must have substantially relied on the interpretation. ${ }^{120}$ These limitations ensure that the Alaska Hunters doctrine will not interfere with the agency process of tentatively working through interpretive issues. ${ }^{121}$

\section{Policy Implications of Alaska Hunters}

\section{A. Policy Benefits of Alaska Hunters}

The Alaska Hunters doctrine is more consistent with both the broad purposes of the APA and traditional notions of procedural fairness than the American Mining approach. ${ }^{122}$ The Alaska Hunters doctrine reinforces the importance of notice-and-comment rulemaking by preventing agencies from making substantial policy changes through the interpretive rule exemption. ${ }^{123}$ According to Professor Robert Anthony, "[t]he statutory procedures for developing legislative rules serve values that have deep importance for a fair

116. Alaska Prof'l Hunters Ass'n v. FAA, 177 F.3d 1030, 1035-36 (D.C. Cir. 1999).

117. See Darrell Andrews Trucking, Inc. v. Fed. Motor Carrier Safety Admin., 296 F.3d 1120, 1126 (D.C. Cir. 2002); Ass'n of Am. R.R.s v. Dep't of Transp., 198 F.3d 944, 949 (D.C. Cir. 1999).

118. See Air Transport, 291 F.3d at 57-58.

119. American Railroads, 198 F.3d at 949-50.

120. Id. at 950 .

121. See id. ("[Applying Alaska Hunters in this case] could prematurely freeze its thinking into a position that it would then be unable to change without formal rulemaking. Not only would this blur the distinction between definitive agency action and informal, uncoordinated communications, it would seriously hamstring agency efforts to interpret and apply their own policies.").

122. Professor Anthony asserts that the importance of notice-and-comment rulemaking to the achievement of the purposes of the APA should compel agencies to use notice-and-comment for significant interpretive changes: "It would champion the worthy precepts of the APA, however, if in certain circumstances agencies would voluntarily make use of notice-and-comment rulemaking procedures to develop interpretive rules." See Anthony, supra note 14, at 1376. Notice-and-comment is often regarded as essential to fairness in the exercise of administrative discretion. According to Professor Kenneth Culp Davis, "[a]nyone and everyone is allowed to express himself and to call attention to the impact of various possible polices on his business, activity, or interest .... The procedure is both fair and efficient." DAvIS, supra note 1 , at 65 .

123. Alaska Prof'l Hunters Ass'n v. FAA, 177 F.3d 1030, 1034 (D.C. Cir. 1999). 
and effective administrative process and indeed for the maintenance of a democratic system of limited government." 124 Notice-and-comment procedures structure the exercise of agency discretion by introducing a measure of due process and public participation into the rulemaking process. ${ }^{125}$ Alaska Hunters advances two important purposes: it guarantees public participation in substantial policy changes and protects the reliance interests of regulated parties.

Notice-and-comment rulemaking ensures that agencies have access to a range of viewpoints and expertise when exercising their discretion, and it also ensures that the public has an opportunity to participate in the formulation of the rules that will govern them. ${ }^{126}$ One of the main purposes of notice-andcomment rulemaking is to provide for well-informed and rational decisionmaking. ${ }^{127}$ Without the limitation placed on amending and reversing definitive interpretations by Alaska Hunters, agencies could essentially reserve certain issues for development and change through interpretive rulemaking by narrowing notice-and-comment rulemaking, thereby eliminating public participation on those issues.

The FAA's actions in Alaska Hunters illustrate this point. In the early 1990 s, the FAA began to study guiding operations in Alaska. ${ }^{128}$ A 1992 FAA report "expressed concern about the safety of guide pilots operating pursuant to [non-commercial air regulations] rather than [commercial air regulations]." 29 The FAA study also concluded that "[a]ny departure from the established practice could have an economical impact on a portion of the commercial guiding populace." 130 In response to the FAA's concerns, the Alaska Professional Hunters Association petitioned the FAA for a rulemaking, proposing guidelines to enhance the safety of guiding operations. ${ }^{131}$ The FAA did not to respond to the petition. ${ }^{132}$ Instead, it issued the "Notice to

124. Anthony, supra note 14, at 1314.

125. See id.

126. See id. at 1373 ("The accuracy and thoroughness of an agency's actions are enhanced by the requirement that it invite and consider the comments of all the world, including those of directly affected persons who are able, often uniquely, to supply pertinent information and analysis."); see also DAVIS, supra note 1 , at 65 .

127. See supra note 126 and accompanying text.

128. Alaska Hunters, 177 F.3d at 1033.

129. $I d$.

130. $I d$.

131. Id.

132. $I d$. 
Operators," which reinterpreted the rule to require guide pilots to comply with the commercial air regulations. ${ }^{133}$

The interpretive change was based on a pure policy judgment regarding the appropriate level of safety regulation for the Alaska guide pilots. ${ }^{134} \mathrm{Had}$ the FAA been able to make the change without notice-and-comment, it effectively would have been able to ignore the alternative view of the Alaska Professional Hunters Association. ${ }^{135}$ Notice-and-comment was designed for precisely this situation, to force agencies to consider all alternatives and therefore provide a basis for well-informed decision-making. ${ }^{136}$ Alaska Hunters reinforces the centrality of notice-and-comment rulemaking to agency policy development by limiting interpretive rules to their proper function of filling in gaps and resolving ambiguities. Once the gaps are filled and the ambiguities are resolved, notice-and-comment is the proper vehicle for effecting policy change.

Alaska Hunters also protects the legitimate reliance interests of regulated parties. ${ }^{137}$ For all practical purposes, the concrete duties and obligations of regulated parties are defined not by the legislative rule, but by the legislative rule as interpreted by the agency. ${ }^{138}$ It is the interpretation that often defines precisely what a party must do or must refrain from doing in order to comply with the law. ${ }^{139}$ Therefore, regulated parties rely on these interpretations in order to make decisions and adjust behavior. ${ }^{140}$

The purpose of an interpretive rule is to reduce uncertainty over how the legislative rule is going to be applied. ${ }^{141}$ These rules benefit regulated parties by informing them of an interpretation and allowing them to proceed on the

133. Id.

134. $I d$.

135. $I d$.

136. See supra note 126 and accompanying text.

137. Alaska Hunters, 177 F.3d at 1035.

138. Supra note 14 and accompanying text. The act of interpretation is necessary in order for the agency to apply the text of the statute or legislative rule to actual events. It is therefore the interpretation that is most consequential to regulated parties. The Alaska guide pilots are a case in point. The text of the legislative rule required commercial pilot certification for those persons carrying persons or property by aircraft "for compensation or hire." Alaska Hunters, 177 F.3d at 1031. The text of the rule itself did not indicate to the pilots whether they were governed by the regulations, it was the interpretation of the text by the Alaskan Division of the FAA that actually determined the issue. Id.

139. See supra notes 14-16 and accompanying text.

140. See supra notes $72-74$ and accompanying text.

141. See Peter L. Strauss, The Rulemaking Continuum, 41 Duke L.J. 1463, 1481 (1992) ("By informing the public how the agency intends to carry out an otherwise discretionary task, publication rulemaking permits important efficiencies to those who must deal with government."). 
basis of the interpretation. ${ }^{142}$ The benefits of a definitive agency interpretation are achieved only when regulated parties "let their guard down" and act on the basis of the interpretation. When agencies are allowed to amend or reverse a definitive agency interpretation without notice-and-comment, the signal to regulated parties is that they should "keep their guard up" because the interpretation can be changed without notice to the regulated parties and, consequently, without an opportunity for them to participate in the formulation of the new interpretation. ${ }^{143}$ If regulated parties cannot have confidence that agency interpretations will not change without the opportunity for participation through notice-and-comment, the cost of regulatory compliance will increase and economic efficiency will correspondingly decrease. Regulated parties will reduce their reliance on definitive interpretations, spending more resources on compliance and foregoing economic opportunities that require a stable and predictable regulatory environment. Notice-and-comment provides an important protection to regulated parties by guaranteeing them at least the opportunity to submit their own proposals and data regarding the potential interpretive change. ${ }^{144}$ In this way, the Alaska Hunters doctrine recognizes that the ultimate value of interpretive rulemaking is contingent upon adequate protection of reliance interests.

The Alaska Hunters doctrine recognizes that it is necessary for courts to distinguish between interpretive rules that fill in gaps and resolve ambiguities and interpretive rules that effectively amend definitive interpretations. The latter implicate important values such as public participation in rulemaking and protection of reliance interests that can only be protected by requiring notice-and-comment.

\section{B. Response to Criticisms of Alaska Hunters}

Some commentators argue that the Alaska Hunters doctrine increases arbitrary agency action and hinders agency flexibility to react to changing circumstances. ${ }^{145}$ These concerns are largely overstated. To the extent that

142. See id.

143. See Anthony, supra note 14, at 1376. Had the Association known that at any time the FAA could subject the guide pilots to commercial regulations, presumably they would have participated in rulemakings regarding those regulations throughout the thirty-year period they were exempt. Alaska Hunters, 177 F.3d at 1035.

144. See supra note 126 and accompanying text.

145. See Pierce, supra note 16, at 571; Connolly, supra note 40, at 171-72. 
they are legitimate, they are more appropriately addressed by reforming notice-and-comment rulemaking procedures.

Professor Richard Pierce, a forceful critic of Paralyzed Veterans and Alaska Hunters, argues that requiring agencies to use notice-and-comment procedures to amend interpretive rules will discourage agencies from issuing interpretive rules at all. ${ }^{146}$ Because of the burdens of changing an interpretation through notice-and-comment, agencies will avoid establishing any definitive interpretation and will merely allow interpretations to develop through ad hoc adjudications. ${ }^{147}$ The American Mining court took a similar view when it argued that unnecessary limitations on interpretive rulemaking would result in ad hoc interpretations that provided less notice to regulated parties. ${ }^{148}$ Therefore, according to this line of argument, interpretive responsibility will devolve to lower-level decision-makers, resulting in the likelihood of "inter-agency contradiction and inconsistency" and "low-level and low-visibility" decision-making. ${ }^{49}$ Regulated parties will not be able to determine with any certainty what interpretation the agency will adopt in a given proceeding. ${ }^{150}$

This critique overlooks the significant incentive agencies still have to issue interpretive rules even when restricted by the Alaska Hunters doctrine: the benefit of unchallenged compliance with interpretative rules due to their "practical binding" nature. ${ }^{151}$ Because interpretive rules are "practical[ly] binding," regulated parties usually adjust their behavior to comply with the interpretation. ${ }^{152}$ However, in the absence of a definitive interpretation from the agency, regulated parties have no such guidance for their actions. The agency will have to therefore engage in increased enforcement action and litigation to achieve the same level of compliance that would be achieved by simply notifying regulated parties of their duties and obligations through an interpretive rule. Thus, the agency benefits substantially by issuing interpretations that provide specific guidance to regulated parties. When parties know exactly what is expected of them ahead of time, they will likely comply, thereby reducing the need to engage in costly enforcement and litigation. ${ }^{153}$

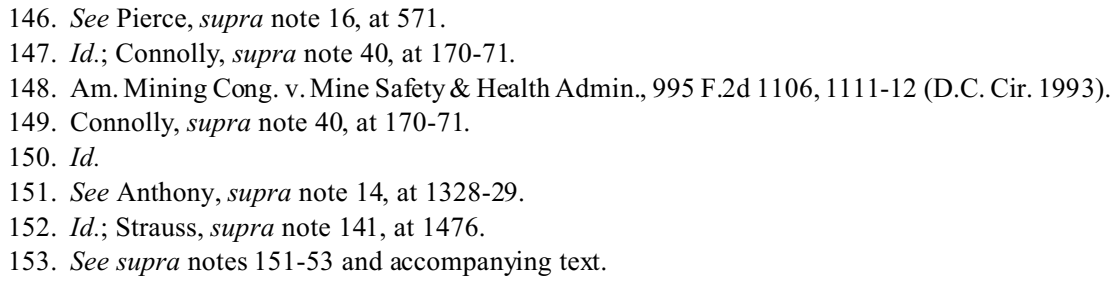


The Alaska Hunters doctrine does not affect the incentive for agencies to conserve resources. It is unlikely that agencies will drastically cut back their interpretive rulemaking activities and shoulder increased enforcement and litigation costs in order to avoid the potential costs of notice-and-comment rulemaking associated with interpretive changes, especially since it is uncertain whether it will even be necessary to amend or reverse the interpretation.

The other major argument levied against the Alaska Hunters doctrine is that it unnecessarily limits agency rulemaking flexibility. ${ }^{154}$ By requiring notice-and-comment for interpretive rules that amend prior definitive interpretations, the doctrine limits an agency's ability to respond to both informational changes and political changes. ${ }^{155}$ According to this argument, an agency must be able to respond quickly to new facts that were not known at the time of the initial interpretation. ${ }^{156}$ Likewise, an agency must be able to respond to changes in the political climate. ${ }^{157}$ Critics view Alaska Hunters as placing unnecessary limits on an important agency tool for responding to informational and political change. ${ }^{158}$

By limiting the utility of interpretive rulemaking as an alternative to notice-and-comment rulemaking, the Alaska Hunters doctrine reaffirms the centrality of notice-and-comment to agency policy development. ${ }^{159}$ Noticeand-comment rulemaking is the best method for responding to informational and political changes. ${ }^{160}$ The opportunity for public comment ensures that agencies receive a variety of perspectives on both the informational and political implications of a proposed interpretive change. To the extent that the increasing burdens of notice-and-comment rulemaking have made it less effective as a tool for responding to informational and political changes, reform should focus on lessening those burdens, not on circumventing noticeand-comment altogether through interpretive rulemaking.

Agencies are unlikely to substantially reduce their interpretive rulemaking due to Alaska Hunters. Critics predicting this result are not taking into account the limited scope of the Alaska Hunters doctrine and the costeffectiveness of interpretive rulemaking as a method of controlling regulated

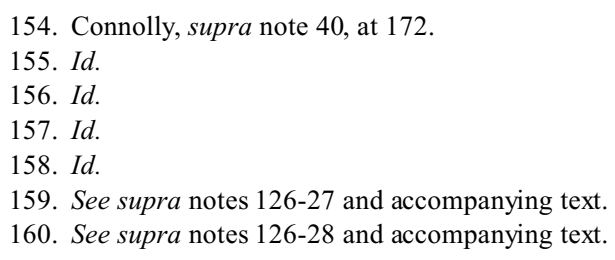


parties. Alaska Hunters serves only to limit the use of interpretive rulemaking for policy changes and, therefore, properly focuses attention on the effectiveness of notice-and-comment procedures in responding to change.

\section{A Critical Look at Judicial Review of Interpretive Rules}

It is necessary to address briefly the issue of judicial review of interpretive rules. All agency actions, including interpretations of legislative rules, are subject to judicial review in which the court "shall decide all relevant questions of law, interpret constitutional and statutory provisions, and determine the meaning or applicability of the terms of an agency action." Under APA $\S 706(2)(a)$, the reviewing court must set aside any agency action found to be "arbitrary, capricious, an abuse of discretion, or otherwise not in accordance with law." 162 Some critics of Alaska Hunters argue that the availability of independent judicial review of interpretive rules is sufficient to vindicate the interests of regulated parties. ${ }^{163}$ According to this view, Alaska Hunters is unnecessary because all agency interpretations can be challenged in court. ${ }^{164}$ This argument is ultimately unpersuasive for two reasons: First, existing judicial review doctrine is extremely deferential to agency interpretations of their own legislative rules, making it unlikely that courts will set aside an agency interpretation; and second, the assertion that judicial review of interpretations provides adequate protection for regulated parties misconceives the fundamental purpose of Alaska Hunters, which is to ensure procedural fairness, rather than ensure the reasonableness of an agency interpretation.

Agency interpretations of their own legislative rules are accorded considerable deference by reviewing courts. Under the current standard, established by the Supreme Court in Bowles v. Seminole Rock and recently reaffirmed in Auer v. Robbins, the court grants controlling weight to an agency's interpretation of its own rule unless it is "plainly erroneous or inconsistent with the regulation." 165 Seminole Rock deference is often equated with the strongly deferential doctrine articulated in Chevron v. Natural

161. 5 U.S.C. $\S 706(2000)$.

162. Id. at $\S 706(2)(a)$.

163. Connolly, supra note 40, at 177.

164. Id. (1945).

165. Auer v. Robbins, 519 U.S. 452, 461 (1997); Bowles v. Seminole Rock, 325 U.S. 410, 414 
Resources Defense Council..$^{166}$ The Chevron doctrine is the deference standard for agency interpretation of statutes. ${ }^{167}$ Therefore, in the context of legislative rules, courts engage in a very narrow review of the agency interpretation and are unlikely to afford any practical relief to regulated parties.

On a more fundamental level, judicial review of agency interpretations and the Alaska Hunters doctrine each serve distinct purposes. The purpose of judicial review of agency interpretations is to determine substantive validity, while the purpose of the Alaska Hunters doctrine is to ensure procedural fairness. Alaska Hunters is concerned with the process by which an agency changes a definitive interpretation, not the substantive merit of the interpretation. Under Alaska Hunters, even if the proposed interpretation is a better reading of the rule than the prior interpretation, notice-and-comment is still required. ${ }^{168}$ Substantive judicial review merely evaluates the interpretation in relation to the rule to ensure that the agency does not exceed its authority. ${ }^{169}$ If the interpretation meets the deferential Seminole Rock standard, the interpretation is valid, regardless of whether the agency considered possible alternatives. These fundamentally different purposes require different doctrinal tools for their achievement.

Given the current level of deference accorded to agency interpretations by the court, judicial review of the interpretation is unlikely to vindicate the interests of regulated parties. ${ }^{170}$ Even if the court engaged in a more probing review of agency interpretations, the nature and purpose of substantive judicial review is such that it cannot vindicate the procedural fairness interests that are the primary focus of Alaska Hunters.

This Part argues that the Alaska Hunters doctrine promotes public participation in substantial policy changes and protects the reliance interests of regulated parties. The result is greater efficiency and fairness in agency rulemaking. Efficiency is served by forcing agencies to consider alternative views and data when making substantial interpretive changes, which facilitates

166. Chevron v. Natural Res. Def. Council, 467 U.S. 837 (1984).

167. PierCe, supra note $34, \S 3.2$, at $139-42$.

168. The facts of Alaska Hunters illustrate this point. The FAA proposed to change the interpretation of "for compensation or hire" to include hunting guide pilots because the cost of the flight was included in the overall price of the hunting trip. See Alaska Prof'l Hunters Ass'n v. FAA, 177 F.3d 1030, 1033 (D.C. Cir. 1999). This makes at least as much, if not more, interpretive sense as exempting the guide pilots on the theory that the flights were "merely incidental" to the guiding business. Id. at 1031.

169. See supra notes $162-63$ and accompanying text.

170. Connolly, supra note 40, at 177. 
rational decision-making. ${ }^{171}$ Fairness is served by guaranteeing the public an opportunity to participate in substantial changes in the laws and by protecting the public from abrupt changes in the definitive interpretations upon which they legitimately relied. ${ }^{172}$ This Part further argues that agencies will not reduce interpretive rulemaking in light of Alaska Hunters because there are still significant incentives to inform the public of agency interpretations through interpretive rules. Finally, this Part rejects the argument that independent judicial review of interpretations is sufficient to vindicate the interests of regulated parties. Alaska Hunters is necessary to ensure procedural fairness in interpretive rulemaking.

\section{Doctrinal Justifications}

The D.C. Circuit Court invited criticism of its doctrinal innovation by failing to offer adequate support for the doctrine in either the Alaska Hunters or Paralyzed Veterans opinions. ${ }^{173}$ In Paralyzed Veterans, the court established the doctrine briefly in dicta, citing only the APA and two cases, neither of which clearly supported the doctrine. ${ }^{174}$ Alaska Hunters then relied solely on the Paralyzed Veterans opinion. ${ }^{175}$ The lack of firm textual or precedential support has led to criticism that Alaska Hunters is doctrinally unsound. ${ }^{176}$ However, despite the lack of a clearly articulated rationale in the opinions, Alaska Hunters can be justified doctrinally as adopting a functional interpretation of the interpretive rule exemption in order to ensure that the exemption is properly limited.

\section{A. Functional Equivalence}

Basically, Alaska Hunters can be read as a recognition that an interpretive rule can, through continuous and repeated application, essentially become part of the legislative rule it interprets. ${ }^{177}$ At a certain point, an agency relies so

171. See supra notes $126-27$ and accompanying text.

172. $I d$.

173. See Pierce, supra note 16, at 567-68 (criticizing the Paralyzed Veterans decision).

174. $I d$.

175. Alaska Prof'l Hunters Ass'n v. FAA, 177 F.3d 1030, 1033 (D.C. Cir. 1999).

176. See Pierce, supra note 16 , at 573.

177. This seems to be the implicit approach of the court in Alaska Hunters. The court states, "[w]hen an agency has given its regulation a definitive interpretation, and later significantly revises that interpretation, the agency has in effect amended its rule, something it may not accomplish without notice and comment." Alaska Hunters, 177 F.3d at 1034. 
consistently on an interpretation, and it becomes so ingrained in the regulatory scheme, that regulated parties no longer distinguish between the rule and the rule as interpreted by the agency. The Alaska Hunters doctrine asserts that once this distinction disappears for regulated parties, the interpretation becomes a part of the rule and is no longer an independent interpretive rule falling under the exemption. It does this by limiting the definition of an interpretive rule to exclude those rules that are technically interpretive, but in reality have become inseparable from a legislative rule. ${ }^{178}$ This raises the basic question: How does the court justify elevating a rule that was initially interpretive and exempt from notice-and-comment to the status of a legislative rule? Logic seems to dictate that if the rule were initially interpretive, it would always be interpretive, unless its status was changed by the agency itself. ${ }^{179}$ From the perspective of regulated parties however, this transformation makes sense. When a legislative rule is promulgated, regulated parties are aware of the gaps and ambiguities. At this initial point, regulated parties are on notice of the different possible interpretations an agency might adopt. ${ }^{180}$ However, once an interpretation is settled and the agency consistently acts on the basis of that interpretation, regulated parties do not maintain the same level of alertness to possible alternative interpretations. ${ }^{181}$ They treat the interpretation as if it was a part of the legislative rule itself. Therefore, any attempt to amend or reverse the interpretation is functionally equivalent to an amendment or reversal of the rule itself, which can only be done through notice-and-comment. The more formal approach to the interpretive exemption fails to recognize this basic reality.

\section{B. Alaska Hunters and Vermont Yankee}

Some commentators have suggested that Alaska Hunters is inconsistent with the Supreme Court's ruling in Vermont Yankee Nuclear Power Corp. $v$. Natural Resources Defense Council ${ }^{182}$ because it imposes procedures on rulemaking beyond those required by the APA. ${ }^{183}$ In Vermont Yankee, the Court stated that "[a]gencies are free to grant additional procedural rights in

178. See supra note 31 and accompanying text. 1993)).

179. See Pierce, supra note 16, at 567 n.136 (citing White v. Shalala, 7 F.3d 296, 304 (2d Cir.

180. See Anthony, supra note 14, at 1376.

181. This is demonstrated by the Alaska guide pilots' lack of attentiveness to the numerous rulemakings regarding the commercial pilot regulations. Alaska Hunters, 177 F.3d at 1035-36.

182. Vt. Yankee Nuclear Power Corp. v. Natural Res. Def. Council, 435 U.S. 519 (1978).

183. Funk, supra note 12, at 1329-30. 
the exercise of their discretion, but reviewing courts are generally not free to impose them if the agencies have not chosen to grant them." 184 The Court further stated that

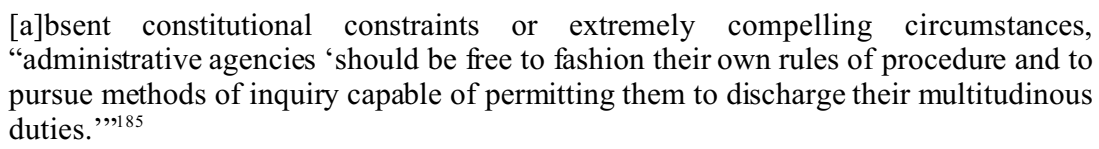

In Vermont Yankee, the Supreme Court halted a common practice of courts of imposing additional procedures (such as testimony and cross-examination) on notice-and-comment rulemaking. ${ }^{186}$ In Alaska Hunters, the court imposed additional procedures in the form of notice-and-comment on interpretive rulemaking. ${ }^{187}$ According to critics, the situation in Alaska Hunters is sufficiently analogous to the situation in Vermont Yankee to require application of the Vermont Yankee prohibition on judicially imposed rulemaking procedure. ${ }^{188}$ However, the Vermont Yankee prohibition is not applicable to Alaska Hunters for two reasons: First, the concerns that motivated the Court in Vermont Yankee are not implicated by Alaska Hunters, and, second, even if Vermont Yankee is applied, Alaska Hunters can be construed as an "extremely compelling circumstance" exempted from the prohibition by the Vermont Yankee Court. ${ }^{189}$

The emanating purpose of Vermont Yankee is to protect the notice-andcomment rulemaking procedure from being transformed by courts into a formal trial-like process. ${ }^{190}$ The Court gave three basic reasons for its holding, none of which are applicable to Alaska Hunters.

First, according to the Court, the judicial effort to fine-tune the factfinding process by adding procedure would result in such unpredictability that agencies would adopt full adjudicatory procedures for every rulemaking in order to avoid legal challenge. ${ }^{191}$ This would effectively eliminate the benefits of informal, notice-and-comment rulemaking. ${ }^{192}$ This concern is not implicated by Alaska Hunters because its application is not unpredictable. It

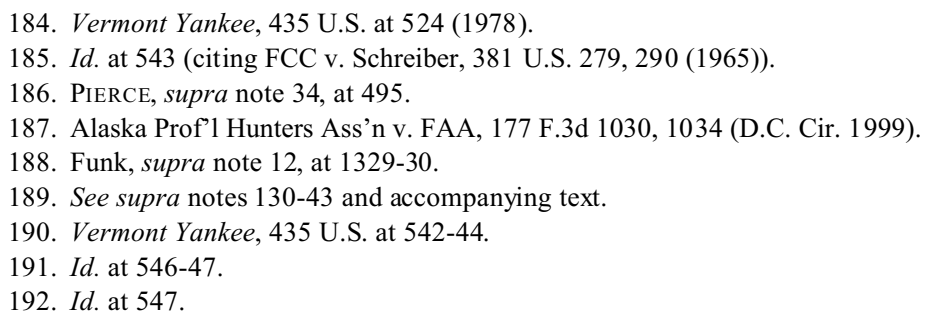


does not attempt to calibrate procedures to each specific factual context as the pre-Vermont Yankee courts did. ${ }^{193}$ The procedural requirement of the doctrine is simple and transparent: notice-and-comment rulemaking. ${ }^{194}$

Another concern of the Court in Vermont Yankee is that courts were making procedural decisions based on the rulemaking record, while the agency was making its procedural decisions before the rulemaking. ${ }^{195}$ In this form of "Monday morning quarterbacking," the courts based their decision on information the agency could not know at the time it established the rulemaking procedure. ${ }^{196}$ In contrast, the Alaska Hunters doctrine is based on the definitiveness of the prior interpretation, something the agency can assess before any effort is made to amend or reverse it. ${ }^{197}$ The agency assesses the definitiveness of an interpretation based on the interpretive documents in force at the time of the proposed interpretive change. This is the same information used by a court when applying Alaska Hunters.

Finally, Vermont Yankee was concerned that courts were compelling agencies to justify their decisions in terms of a full adjudicatory record, when the production of such a record is not necessarily advantageous in the informal rulemaking proceeding. ${ }^{198}$ Alaska Hunters is concerned only with ensuring procedural fairness in the context of substantial interpretive changes. ${ }^{199}$ Alaska Hunters calls only for notice-and-comment procedures, and only in the context of substantial interpretive changes. ${ }^{200}$ Alaska Hunters can arguably be viewed as a complementary doctrine to Vermont Yankee in the effort to preserve the relevance of notice-and-comment rulemaking. Vermont Yankee limits the drift up to formal rulemaking caused by the courts while Alaska Hunters limits the drift down to interpretive rulemaking caused by the agencies. Both act to preserve the vital center of agency rulemaking: the notice-and-comment procedure.

Vermont Yankee did not impose an absolute prohibition on additional procedure. ${ }^{201}$ It left exceptions for "constitutional constraints or extremely compelling circumstances." ${ }^{202}$ Given the fundamental fairness issues

193. See id. at 546-47.

194. Alaska Prof'l Hunters Ass'n v. FAA, 177 F.3d 1030, 1033-34 (D.C. Cir. 1999).

195. Vermont Yankee, 435 U.S. at 547.

196. $I d$.

197. Alaska Hunters, 177 F.3d at 1034.

198. Vermont Yankee, 435 U.S. at 547.

199. See Alaska Hunters, 177 F.3d at 1035-36.

200. Id. at 1034-36.

201. Vermont Yankee, 435 U.S. at 543.

202. $I d$. 
involved, Alaska Hunters could also be viewed as giving substance to the exception for "extremely compelling circumstances." 203

In the case of Alaska Hunters, the definitive interpretation had been relied on by a whole industry composed of small businesses for over thirty years. ${ }^{204}$ With no opportunity to comment, the FAA attempted to subject the hunting guide industry to an entire class of regulations from which it had been previously exempt. ${ }^{205}$ That the industry relied in good faith on consistent, uniform advice from the agency, and that they had an alternative proposal to deal with the safety concerns, indicates that there were substantial fairness values at stake in at least allowing the Alaska Professional Hunters Association to be heard in the rulemaking process. ${ }^{206}$ Given the level of potential harm to the industry and the relative modesty of their request (only that the FAA engage in notice-and-comment rulemaking to change the interpretation, not an estoppel on government action altogether), it can be argued persuasively that this is the type of situation that the Vermont Yankee Court had in mind when it fashioned the narrow exceptions.

This Part argues that despite its lack of direct precedential support, Alaska Hunters is on firm doctrinal ground. It adopts a functional approach to the interpretive rule exemption in order to prevent the exemption from eroding the relevance of notice-and-comment rulemaking and thereby undermining the purposes of the APA rulemaking procedures. This Part further argues that Alaska Hunters is not inconsistent with Vermont Yankee because it does not implicate any of the concerns that motivated the Court in Vermont Yankee and, in the alternative, it can reasonably be held to fall under the narrow "extremely compelling circumstances" crafted by the Vermont Yankee Court.

\section{CONCLUSion}

Interpretive rulemaking is central to effective agency administration. ${ }^{207}$ Both agencies and regulated parties benefit when agencies are able to fill in gaps and resolve ambiguities in regulations through interpretive rules. ${ }^{208}$ However, interpretive rulemaking can be unfair and inefficient when it is used to amend or reverse definitive interpretations upon which regulated parties

203. $I d$.

204. Alaska Hunters, 177 F.3d at 1035.

205. Id. at 1035-36.

206. See supra notes $72-75$ and accompanying text.

207. Supra note 14 and accompanying text.

208. Supra note 141 and accompanying text. 
legitimately relied. Once interpretive gaps and ambiguities are resolved, regulated parties must be confident that the issues are settled and any substantive changes will occur only after given an opportunity to participate through notice-and-comment rulemaking. ${ }^{209}$ Notice-and-comment guarantees interested parties an opportunity to present their views to the agency and gives them a measure of procedural protection for their reliance interests. ${ }^{210}$

This Note argues that the Alaska Hunters doctrine strikes the right balance between agency flexibility and stability in interpretive rulemaking. It gives agencies considerable flexibility in resolving interpretive issues, but once interpretations are settled, it requires that agencies use notice-andcomment rulemaking to amend or reverse these definitive interpretations. ${ }^{211}$ Notice-and-comment serves two basic purposes: It ensures public participation in substantial policy changes and protects the reliance interests of regulated parties. Essentially, the Alaska Hunters doctrine recognizes the basic reality that when interpretations are applied consistently over time, they become inseparable from the legislative rule itself. ${ }^{212}$ At this point, basic procedural fairness requires that courts treat these interpretations as part of the legislative rules. Therefore, this Note concludes that courts should adopt the Alaska Hunters approach to interpretive rules that amend or reverse definitive interpretations and abandon the more formalistic approach represented by American Mining.

209. Supra notes 143-44 and accompanying text.

210. Supra note 126 and accompanying text.

211. Alaska Prof'l Hunters Ass'n v. FAA, 177 F.3d 1030, 1034 (D.C. Cir. 1999).

212. Supra notes $178-79$ and accompanying text. 